\title{
Akut Böbrek Hasarında Mortalitede Öncül Faktörler
}

\author{
Premise Factors of Mortality in Acute Kidney Injury \\ Yavuz AYAR ${ }^{1}$, Emel Işıktaş SAYILAR ${ }^{1}$, Alparslan ERSOY ${ }^{1}$, Hakan DÜĞER², Çağatay AK², \\ Abdülkadir GÖÇKEN², Mahmut YAVUZ1 \\ 'Uludağ Üniversitesi Tıp Fakültesi, Nefroloji Bilim Dalı, Bursa \\ ${ }^{2}$ Uludağ Üniversitesi Tıp Fakültesi, İç Hastalıkları Anabilim Dalı, Bursa
}

Geliş Tarihi / Received: 10.04.2014

Kabul Tarihi / Accepted: 02.12.2014

\begin{abstract}
ÖZET
Amaç: Prokalsitonin (PCT), C-Reaktif Protein (CRP), serum amiloid $A(S A A)$, albümin ve serum kolesterol değerleri enflamasyon, enfeksiyon ve malnütrisyonun erken belirteçlerindendir. Akut böbrek hasarının $(\mathrm{ABH})$ gelişiminde enfeksiyon, oral alım bozukluğu, dehidratasyon ve malnütrisyon önemli yer tutmaktadır. Bu etkenlerin erken saptanması tedavide önem arz etmektedir.
\end{abstract}

Gereç ve Yöntem: Ocak 2013-2014 tarihleri arasında Nefroloji Kliniğimizde takip edilen 182 hastaya RIFLE (Risk, injury, failure, loss, end stage renal failure) ve AKIN (acute kidney injury network) kriterlerine göre $\mathrm{ABH}$ tanısı konmuştur. Hastalar nutrisyonel ve enflamatuar belirteçlere göre sağlıklı kontrol grubuyla (52 hasta) kıyaslanmıştır.

Bulgular: $A B H$ da albümin, $C R P$, prokalsitonin ve $S A A$ değerleri hasta grubu lehine, sağlıklı kontrol grubuyla karşılaştırıldığında anlamlı bulunmuştur ( $p<0,001$ ve $p$ $=0,002$ ) Yine lökosit, kolesterol, LDL kolesterol, trigliserit değerleri karşılaştırıldığında ölen $\mathrm{ABH}$ hastalarında yüksek saptanmıştır $(p=0,016, p=0,032, p=0,03$ ve $p$ $=0,026$ ). Ölen hastalarda bu değerlerle beraber enfeksiyonve ek hastalıklar önemli bir etkendi. Enfeksiyonlar arasında sepsis ve pnömoniye rastlanmaktaydı. Hastaların HDL kolesterol değerleri arasında fark saptanmamıştır $(p=0,52)$.

Sonuç: $A B H$ hastalarında enflamasyon, malnütrisyon, sepsis yüksek oranda görülmektedir. $\mathrm{ABH}$ da ölen hastalarda $(\% 4,94)$ CRP, PCT, SAA, albümin, kolesterol değerleri yüksek saptanmış olup bu değerler tedavi ve izlemde önemini korumaktadır.

Anahtar Kelimeler: Enflamasyon, enfeksiyon, malnütrisyon, akut böbrek hasarı.

\section{ABSTRACT}

Objective: Procalcitonin (PCT), C-Reactive Protein, serum amyloid $A(S A A)$ and serum cholesterol values are early markers for inflammation, infection and malnutrition. In development acute kidney injury (AKI) infection, oral intake disorders, dehydratation and malnutrition have important place. These factors are important in the early detection of treatment.

Material and Methods: Between January 2013-2014 in our nephrology clinic followed 182 patients and diagnosed AKI with RIFLE (risk, injury, failure, loss, end stage renal failure) and AKIN (acute kidney injury network) criterias. Patients were compared according to nutritional and inflammatory markers with healthy control group (52 patients)

Results: Albumin, CRP, procalcitonin and SAA values in AKI patients favor compared with healthy control group and results were statistically significant $(p<0.001$ and $p$ $=0.002$ ). Again, leukocytes, cholesterol, LDL cholesterol, triglyceride levels were higher in died AKI patients ( $p=$ $0.016, p=0.032, p=0.03$ and $p=0.026$ ) Addition to these values in patients who died, Infection and comorbidity diseases were important factors. In infections found sepsis and pneumonia. HDL cholesterol levels did not differ between patients $(p=0.52)$.

Conclusion: Inflammation, malnutrition, sepsis are highly prevalent diseases in AKI patients. Patients who died in AKI $(\%$ 4,94), CRP, PCT, SAA, albumin, and cholesterol levels were higher. Treatment and following these values were important.

Keywords: Inflammation, infection, malnutrition, acute kidney injury. 


\section{GíRiş}

Akut böbrek hasarı $(A B H)$ üre ve kreatininde ani yükseklik ile kendini gösteren klinik bir tablodur $(1,2)$. Hastalık böbrek fonksiyon bozukluğunun değişik bulgularıyla karşımıza çıkabilir. Metabolik asidoz ve hiperkalemi, oligüri gibi metabolik hadiseler, anormal sıvı balansı ve diğer organ tutulumları şeklinde gözlenebildiği gibi hastanede yatan asemptomatik hastalarda sadece üre ve kreatinin yüksekliği ile de saptanabilir. Yine $A B H$ ilerleyen periyotlarda son dönem böbrek yetmezliğine dönüşebilmekte ve uzun dönemde önemli bir mortalite nedeni olabilmektedir $(3,4)$. Hastalığın seyrinde ve takibinde enfeksiyon, inflamasyon ve malnütrisyon önemli bir yer işgal etmektedir. ABH da başvuru nedenleri arasında enfeksiyon, oral alım bozukluğu, dehidratasyon vb. şikayetler yer almaktadır. Bu yüzden C-reaktif protein(CRP), serum kolesterol düzeyi, prokalsitonin (PCT), serum amiloid A (SAA), albümin vb. belirteçler klinik takip ve tedavide önemlidir (5-20).

Enfeksiyon belirteçleri arasında CRP, SAA, PCT önemli yer tutmaktadır. Serum CRP karaciğerden sentezlenen ve saatler içinde yükselen önemli markerlardandır. Ucuz olması ve kolay ulaşılabilir olması kullanım pratiği oluşturmaktadır. Enfeksiyon dışında otoimmün hastalıklar, travma, kanser, cerrahi gibi durumlarda da yüksek seyredebilmektedir $(6,7,21,22)$.

Tablo 1: RIFLE ve AKIN sınıflaması.
Prokalsitonin 116 aminoasitten oluşan tiroid C hücrelerinden salınan ve kalsitoninin hormonunun öncül maddesi olan bir belirteçtir. Bakteriyel enfeksiyon ve sepsis durumlarında tanısal olarak değerleri artmaktadır(14-16). Albumin ve prealbümin karaciğerden sentezlenen negatif akut faz reaktanlarındandır. Enfeksiyon, malnütrisyon, enflamasyon durumlarında bu iki değer anlamlı olarak azalmaktadır. SAA da enfeksiyon ve enflamasyon durumlarında hasarlı doku ve organlarda biriken protein agregatlardır (23). Hipokolesterolemi özellikle çoklu organ yetmezliğ, sepsis (sepsise bağlı akut böbrek hasarı), malnütrisyonu olan hastalarda görülen bir tablodur (12).

Böbrek yetmezliğinde sınıflamada kreatinin kullanılan en önemli belirteçlerdendir. Kreatinin böbrek hasarında 48-72 saat sonra artmaya başlar. Kreatinindeki artışlar kliniklere göre farkIılık göstermekte olup renal rezervi normal olan hastalarda da artış görülebilmektedir. Tanımlamada akut böbrek yetmezliği yerine günümüzde artık akut böbrek hasarı ( $\mathrm{ABH}$ ) kullanılmaktadır. ABH tanı ve sınıflamasında RIFLE (Risk, injury, failure, loss, end stage renal disease) ve AKIN (Acute kidney injury network) kriterleri kullanılmaktadır. Günümüzde tanıda her iki kriter KDIGO kılavuzuna göre birlikte kullanılmaktadır (24-27) (Tablo 1).

\begin{tabular}{|c|c|c|}
\hline $\begin{array}{c}\text { RIFLE } \\
\text { SINIFLAMASI }^{5}\end{array}$ & GFR & IDRAR ÇIKIŞ \\
\hline Risk & Serum kreatinin $>1,5$ kat bazal değere göre veya GFR $>\% 25$ azalma & $\begin{array}{c}\text { İdrar çıkışı }<0,5 \mathrm{ml} / \mathrm{kg} / \mathrm{saat} \times 6 \\
\text { saat }\end{array}$ \\
\hline İnjury & Serum kreatinin > 2 kat bazal değere göre veya GFR > \% 50 azalma & $\begin{array}{c}\text { İdrar çıkışı }<0,5 \mathrm{ml} / \mathrm{kg} / \mathrm{saat} \times 12 \\
\text { saat }\end{array}$ \\
\hline Failure & $\begin{array}{c}\text { Serum kreatinin }>3 \text { kat bazal değere göre } \\
\text { GFR }>\% 75 \text { azalma veya Serum kreatinin }>4 \mathrm{mg} / \mathrm{dl}\end{array}$ & $\begin{array}{c}\text { İdrar çıkışı }<0,3 \mathrm{ml} / \mathrm{kg} / \mathrm{saat} \times 24 \\
\text { saat veya anüri x } 12 \text { saat } \\
\end{array}$ \\
\hline Loss & Kalıcı akut renal yetmezlik = Tam fonksiyon kaybı > 4 hafta & \\
\hline ESRD & Son dönem böbrek hastalığı > 3 ay & \\
\hline $\begin{array}{c}\text { AKIN } \\
\text { SINIFLAMASI6 } \\
\text { EVRE }\end{array}$ & SERUM KREATININ & IDRAR ÇIKIŞI \\
\hline 1 & $\begin{array}{c}\text { Serum kreatinin farkında } \geq 0,3 \mathrm{mg} / \mathrm{dl} \text { veya } \\
\text { Serum kreatinin } \geq 1,5, \leq 2 \mathrm{~kat} \text { bazal değere göre }\end{array}$ & $\begin{array}{c}\text { İdrar çıkışı }<0,5 \mathrm{ml} / \mathrm{kg} / \mathrm{saat} \times 6 \\
\text { saat }\end{array}$ \\
\hline 2 & Serum kreatinin $>2, \leq 3$ kat bazal değere göre & $\begin{array}{c}\text { İdrar çıkışı }<0,5 \mathrm{ml} / \mathrm{kg} / \mathrm{saat} \times 12 \\
\text { saat }\end{array}$ \\
\hline 3 & $\begin{array}{c}\text { Serum kreatinin }>3 \mathrm{~kat} \text { bazal değere göre veya } \\
\text { serum kreatinin }>4 \mathrm{mg} / \mathrm{dl}, \geq 0,5 \mathrm{mg} / \mathrm{dl} \text { ani artış veya } \\
\text { renal replasman tedavi ihtiyacı }\end{array}$ & $\begin{array}{c}\text { İdrar çıkışı }<0,3 \mathrm{ml} / \mathrm{kg} / \mathrm{saat} \times 24 \\
\text { saat veya } \\
\text { Anüri x } 12 \text { saat }\end{array}$ \\
\hline
\end{tabular}

RIFLE: Risk, injury, failue, loss, endstagerenaldisease; GFR: Glomerularfiltration rate; ESRD: Endstagerenaldisease, AKIN: AcuteKidneylnjury Network 


\section{GEREÇ ve YÖNTEM}

Uludağ Üniversitesi Tıp Fakültesi Hastanesi Nefroloji Kliniğinde, Ocak 2013-2014 tarihleri arasında başvuran $\mathrm{ABH}$ lıhastalar değerlendirildi. Değerlendirmede KDIGO 2013 kılavuzuna göre AKIN ve RIFLE kriterleri birlikte kullanıldı. Hastalar yaş, cinsiyet, tanılar, başvuru nedenleri, şikayetleri, enfeksiyon varlı̆̆ ve türü, ilaç ve kontrast kullanımı, $\mathrm{ABH}$ ye giriş-çıkış kreatinin değerleri, CRP, PCT, albümin, kolesterol, lökosit, SAA değerleri, oligüri-nonoligüri, diyaliz ihtiyacına ve mortalite bulgularına göre incelendi.

Kronik böbrek yetmezliği (KBY) ve KBY nin akut hecmesinde olan hastalar çalışmaya alınmadı. Kontrol grubu, ek hastalığı olmayan, tamamen sağlıklı gönüllülerden seçilmiştir. Kategorik değişkenler sayı (n) ve yüzde (\%) olarak verilmiştir. Sürekli değişkenler için Wilcoxon testi, gruplar arası karşılaştırmalarda Mann-Whitney testi kullanılmıştır.

\section{BULGULAR}

Ocak 2013-2014 tarihleri arasında 182ABH ve 52 sağlıklı kontrol grubu hastası Nefroloji kliniğimizde değerlendirilmeye alındı. Yaş ortalaması ABH grubunda erkeklerde 65 (18-90), kadınlarda 67 (22-93), kontrol grubunda 38 (21-48) idi. Hastalarımızın \% 50 sinde preerenal, \% 36,81 inde renal ve \% 13,19 unda postrenal kaynaklı $\mathrm{ABH}$ mevcuttu.

Başvuru nedenleri arasında oral alım bozukluğu, ilaç ve kontrast madde kullanımı, enfeksiyon, hidronefroz ön plandaydı. Ek hastalıklar arasında hipertansiyon, tip 2 diyabet ve iskemik kalp hastalığı daha fazla görülmekteydi. Renal $\mathrm{ABH}^{\prime}$ lilerin \% 12,09'unun, prerenal $\mathrm{ABH}$ 'lilerin $\% 8,79$ unun ve postrenal $A B H^{\prime}$ lilerin $\% 2,2$ sinin diyaliz intiyacı vardı.

Ortalama yatış süreleri prerenal $A B H^{\prime}$ lilerde 8 , renal $A B H^{\prime} l i l e r d e ~ 14$, postrenal $A B H^{\prime} l i l e r d e$ 5 gündü. (Tablo 2)

Laboratuar değerleri karşılaştırıldığında, $A B H$ hastaları ile kontrol grubunun albümin değerleri yaşayan $A B H^{\prime} l i l e r d e ~(173$ hasta) 3,1 $\mathrm{g} / \mathrm{L}$, ölenlerde $2,5 \mathrm{~g} / \mathrm{L}$ (9 renal kaynaklı $A B H$ ), kontrol grubunda 3,8 g/L idi. Kontrol grubu ile ölen $A B H$ hastaları arasındaki fark anlamlıydı $(p=0,024)$. Albümin değerleri yaşayan ABH'lilerle kontrol grubu karşılaştırıldığında da anlamlıydı $(p=0,044)$. Lökosit değerleri kıyaslandığında $A B H$ ölen ve yaşayan hastalar ile kontrol grubu kıyaslandığında $\mathrm{ABH}$ hastaları lehine sonuç anlamlı çıkmıştı ( $p$ değeri sırasıyla 0,016 ve 0,038 ). PCT, SAA, CRP ve trigliserit değerleri de $A B H$ hastalarında daha anlamlı tespit edilmişti. HDL kolesterol değerleri arasında anlamlı birfark bulunmamıştı $\quad(p=0,52)$ Laboratuar değerleriyle ilgili veriler Tablo 3 'de paylaşıımıştır (Tablo 3).

Ölen 9 hastanın (\% 4,94) hepsi renal kaynaklı $A B H$ idi ve hepsinde enfeksiyon mevcuttu.

\section{TARTIŞMA}

Akut böbrek hasarı hastanede takip edilen hastalarda mortalite ve morbiditenin en önemli nedenleri arasındadır. Bu hastalarda enflamasyon ve malnutrisyon sık gözlenmektedir. Hastalar oligüri, ödem, oral alım bozukluğu, çoklu organ yetmezliği, enfeksiyon vb. bulgularla başvurabildiği gibi asemptomatikde olabilirler. Enfeksiyon özellikle sepsis, $A B H$ da en önemli mortalite sebepleri arasındadır (1-5).

Yeni Zellanda ve Avustralya'da 120.123 hasta, 57 yoğun bakımı içeren 2000-2005 yılları arasında yapılan bir çalışmada $33.375(\% 27,8)$ sepsis, $14039(\% 42,1)$ septik şoka bağlı ABH tespit edilmiş olup, albümin değerleri anlamlı olarak düşük bulunmuştur $(p<0,001)$. Gaini ve arkadaşlarııı yaptığı bir çalışmada da 194 hasta değerlendirilmiş, 106 hastada sistemik enflamatuar yanıt sendromu ve sepsis görülmüş ve bu hastalarda PCT yüksek tespit edilmiştir $(p<0,001)$. Becker ve arkadaşlarının yaptığı bir analizde sepsis, sistemik enflamasyon ve enfeksiyon olan hastalarda PCT değerleri anlamlı olarak artmış bulunmuştur $(p<0,001)(5,6,16)$.

3917 hastayı içeren 11 çalışmayı inceleyen bir araştırmada serum albümin değerleri $A B H$ ve $A B H$ sonrası ölen hastalarda anlamlı derecede düşük tepit edilmiştir $(p<0,001) .1600$ diyaliz hastasını içeren başka bir çalışmada albümin, prealbümin ve kolesterol değerleri beslenme ölçeği olarak değerlendirilmiş ve protein enerji malnütrisyonu gözlenenlerde bu değerler düşük saptanmıştır $(p<0,001)(7,10)$.

Perez-Valdivieso ve arkadaşlarının yaptığı çalış- 
Tablo2: ABH tanısı alan hastaların klinik özellikleri.

\begin{tabular}{|c|c|}
\hline Özellikler & Hastalar $(n=182)$ \\
\hline CinsiyetOrtalam Yaş & \\
\hline HASTA GRUBU & \\
\hline Kadın (K) $67(22-93)$ & $86(\% 47,25)$ \\
\hline Erkek (E) & $96(\% 52,75)$ \\
\hline KONTROL GRUBU & KONTROL GRUBU ( $n=52)$ \\
\hline $40(20-48)$ & $32(\% 61,5)$ \\
\hline $36(22-48)$ & $20(\% 38,5)$ \\
\hline Başvuru Nedenleri & \\
\hline Prerenal & $91(\% 50)$ \\
\hline Oral alım bozukluğu & $70(\% 38,46)$ \\
\hline Gastroenterit & $21(\% 8,86)$ \\
\hline Renal & $67(\% 36,81)$ \\
\hline NSAii, antibiyotik vd. & $21(\% 11,54)$ \\
\hline Kontrast & $19(\% 10,44)$ \\
\hline Rabdomiyoliz & $7(\% 3,85)$ \\
\hline HELLP, HÜS & $5(\% 2,75)$ \\
\hline Sepsis & $15(\% 8,24)$ \\
\hline Postrenal & $24(\% 13,19)$ \\
\hline Hidronefroz & $18(\% 9,89)$ \\
\hline $\mathrm{BPH}$, infravezikal darlık & $6(\% 3,3)$ \\
\hline Enfeksiyon Dağılımı & \\
\hline Prerenal & $15(\% 8,24)$ \\
\hline Pnömoni & $8(\% 4,4)$ \\
\hline Üriner & $2(\% 1,1)$ \\
\hline Gastroenterit & $5(\% 2,75)$ \\
\hline Renal & $22(\% 12,09)$ \\
\hline Üriner & $10(\% 5,5)$ \\
\hline Sepsis & $8(\% 4,4)$ \\
\hline Pnömoni & $6(\% 3,3)$ \\
\hline Gastroenterit & $1(\% 0,55)$ \\
\hline Postrenal & $4(\% 2,2)$ \\
\hline Üriner & $4(\% 2,2)$ \\
\hline Ek Hastalıklar & \\
\hline Hipertansiyon (HT) + Tip $2 \mathrm{DM}$ & $37(\% 20,33)$ \\
\hline HT & $34(\% 18,68)$ \\
\hline HT + İskemik Kalp Hastalığı (IKH) & $15(\% 8,24)$ \\
\hline Kanser & $14(\% 7,69)$ \\
\hline HT + IKH +Tip 2 DM & $11(\%, 6,04)$ \\
\hline Tip 2 DM & $11(\%$ 6,04) \\
\hline Diğer & $18(\% 9,89)$ \\
\hline Yok & $33(\% 18,13)$ \\
\hline ABH da Diyaliz & \\
\hline Prerenal & $16(\% 8,79)$ \\
\hline Oligüri & $6(\% 3,3)$ \\
\hline Non-oligüri & $10(\% 5,5)$ \\
\hline Renal & $22(\% 12,09)$ \\
\hline Oligüri & $15(\% 8,24)$ \\
\hline Non-oligüri & $7(\% 3,85)$ \\
\hline Postrenal & $4(\% 2,2)$ \\
\hline Oligüri & $4(\% 2,2)$ \\
\hline Ortalama hastaneye yatış süresi & \\
\hline Prerenal & $8(6-14)$ \\
\hline Kadın & $8(6-14)$ \\
\hline Erkek & $10(6-12)$ \\
\hline Renal & $14(10-37)$ \\
\hline Kadın & $14(10-37)$ \\
\hline Erkek & $16(12-34)$ \\
\hline Postrenal & $5(4-11)$ \\
\hline Kadın & $5(4-9)$ \\
\hline Erkek & $5(5-11)$ \\
\hline Kreatinin Ortalama & \\
\hline ABH Giriş & $3,73(1,5-14,1)$ \\
\hline $\mathrm{ABH}$ Çıkış & $1,1(0,5-6,5)$ \\
\hline Mortalite & \\
\hline Renal & $9(\% 4,94)$ \\
\hline Kadın (Ortalama Yaş 56) & $4(\% 2,2)$ \\
\hline Erkek (Ortalama Yaş 68,8) & $5(\% 2,74)$ \\
\hline
\end{tabular}


Tablo3: Laboratuar değerleri.

\begin{tabular}{|c|c|c|c|c|c|}
\hline LABORATUAR & NORMAL DEĞER ARALIĞI & $\begin{array}{l}\text { ABH hastalar } \\
\text { Yaşayanlar }(n=173)\end{array}$ & Ölenler ( $n=9$ ) & $\begin{array}{l}\text { Kontrol Grubu } \\
(n=52)\end{array}$ & p değeri (Ö-Kgrubu, Y-K grubu) \\
\hline Lökosit & $(4,6-11,2 \mathrm{~K} / \mu \mathrm{L})$ & $8,63(2,57-85,4)$ & $13,21(12,62-21,5)$ & $6,52(4,21-8,47)$ & $0,016,0,038$ \\
\hline Albümin & $(4-5 \mathrm{~g} / \mathrm{L})$ & $3,1(1,6-4,6)$ & $2,5(1,7-3,3)$ & $3,8(3,6-4,2)$ & $0,024,0,044$ \\
\hline CRP & $(<0,5)$ & $3,86(0,3-21)$ & $6,21(2,13-32)$ & $1,89(0,5-3,8)$ & $0,001,0,021$ \\
\hline \multicolumn{2}{|c|}{ Prokalsitonin $(<0,05)$} & $1,28(0,05-25,7)$ & $2,97(2,32-87,5)$ & $0,17(0,05-4,02)$ & $0,001,0,017$ \\
\hline Total Kolesterol & $(130-200 \mathrm{mg} / \mathrm{dL})$ & $176(55-304)$ & $134(47-184)$ & $185(128-425)$ & $0,032,0,252$ \\
\hline \multicolumn{2}{|c|}{ LDL Kolesterol $(60-130 \mathrm{mg} / \mathrm{dL})$} & $106,5(10-274)$ & $71(23-158)$ & $123(98-186)$ & $0,03,0,057$ \\
\hline Trigliserit & (40-150 mg/dL) & $130(22-271)$ & $78(56-138)$ & $155(102-675)$ & $0,026,0,046$ \\
\hline \multicolumn{2}{|c|}{ HDL Kolesterol ( $>40 \mathrm{mg} / \mathrm{dL}$ ) } & $32,5(5-57)$ & $30(12-38)$ & $42(28-52)$ & $0,52,0,55$ \\
\hline Serum Amiloid A & $(<6,8 \mathrm{mg} / \mathrm{L})$ & $7,22(0-15,3)$ & $9,86(5,86-18.63)$ & $3,14(0-7,21)$ & $0,001,0,011$ \\
\hline
\end{tabular}

O-K grubu: Ölenler kontrol grubu, Y-K grubu: Yaşayanlar kontrol grubu

mada 2000-2006 yılları arasında incelenen hastalarda $A B H^{\prime} l i$ ve $A B H$ sonrası ölen hastalarda CRP değerlerini anlamlı derecede yüksek, prealbümini düşük bulmuşlardır $(p<0,001)$. Çoklu organ yetmezliği olan 70 hastayla ilgili yapılan bir değerlendirmede CRP, CRP/prealbumin değerleri yüksek, prealbümin düşük tespit edilmiştir $(p<0,001)(11,13)$.

Enguix ve arkadaşlarının çocuklarda yaptığı bir çalışmada 116 çocuk hasta dört gruba ayrılarak incelenmiş, sepsis gözlenen hastalarda $S A A, C R P$ ve $P C T$ değerleri yüksek bulunmuştur $(p<0,001) .240 \mathrm{ABH}$ hastasının değerlendirildiği bir araştırmada da albumin ve serum kolesterol düzeyleri anlamlı olarak düşük gözlenmiştir $(p<0,001)(17,18)$.

Çin'de yapılan bir çalışmada 2011 yılında incelenen 1361 hasta içinde sepsise bağlı ABH görülenlerde $P C T, S A A$ ve $C R P$ yüksek tespit edilmiştir. Yine hastanede yatan $\mathrm{ABH}$ I 155 hasta değerlendirildiğinde CRP, CRP/prealbümin, CRP/albümin, CRP/kolesterol oranları yüksek bulunmuştur $(p<0,001)(19,20)$.

Yaptığımız çalışmada $\mathrm{ABH}$ tanısı konan hastalar yaşayan ve ölenler ile sağlıklı kontrol grubu karşılaştırılmıştı. Kontrol grubunun yaş ortalaması hasta grubu ile kıyaslandığında daha düşüktü (Ortalama yaş 38). Bunda ek hastalığın olmayanların seçilmesi etken olmuştur. Serum albümin ve lökosit değerleri $\mathrm{ABH}$ olan hastalarda, kontrol grubuyla karşılaştırıldığında anlamIı derecede düşük gözlenmiştir ( $p=0,024, p=$ $0,016)$. Kolesterol değerleri arasında LDL kolesterol ve total kolesterol değerleri ölen $A B H$ lılar ile sağlıklı grup karşılaştırıldığında düşük tespit edilmişti $(p=0,03, p=0,026)$. Yaşayan ABH hastalarında bu değerler kontrol grubuyla kıyas- landığında anlamlı çıkmamıştır ( $p>0,05)$. HDL kolesterol sonuçları arasında anlamlı bir fark saptanmamıştı $(p=0,52)$. Çalışmamızda CRP, $P C T$ ve SAA değerleri de kontrol grubuyla karşılaştırıldığında $A B H$ lıyaşayan hastalar ve $A B H$ dan ölen hastalarda anlamlı derecede yüksek bulunmuştu (Tablo 3).

\section{SONUÇ}

Akut böbrek hasarı görülme oranlarında son dönemlerde tedavi ve tanı olanaklarının gelişmesiyle beraber düşme gözlenmiştir. Özellikle hastanede yatan, yoğun bakımlarda takip edilen hastalarda mortalite hala yüksek seyretmektedir. Enfeksiyon ile mücadele ve hastaların erken rehabilitasyonu açısından beslenme sağ kalımı etkilemektedir. Bu yüzden tanı, tedavi ve izlemde üre ve kreatinin ile elektrolit değerlerinin yanında CRP, PCT, SAA, albümin ve kolesterol değerleri enfeksiyon, enflamasyon ve malnütrisyonu değerlendirme bakımından önem arz etmektedir.

\section{KAYNAKLAR}

1. Palevsky PM. Epidemiology of acute renal failure: The tip of the iceberg. Clin J Am Soc Nephrol 2006;1(1):6-7.

2. Ympa YP, Sakr Y, Reinhart K, Vincent JL. Has mortality from acute renal failure decreased? A systematic review of the literature. Am J Med 2005;118(8):82732.

3. Macedo E, Bouchard J, Mehta RL. Renal recovery following acute kidney injury. Curr Opin Crit Care 2008; 14(6):660-5.

4. Ishani A, Xue JL, Himmelfarb J, et al. Acute kidney injury increases risk of ESRD among elderly. J Am Soc Nephrol 2009;20(1):223-28. 
5. Bagshaw SM, George C, Bellomo R. Early acute kidney injury and sepsis: a multicentre evaluation. Crit Care 2008;12(47):1-9.

6. Gaini S, Koldkjaer OG, Pedersen C, Pedersen SS. Procalcitonin, lipopolysaccharide-binding protein, interleukin- 6 and C-reactive protein in community-acquired infections and sepsis: A prospective study. Crit Care 2006;10(2):53.

7. Anderson $R$, Schmidt R. Clinical biomarkers in sepsis. Front Biosci (Elite Ed) 2010;2(1):504-20.

8. Wiedermann CJ, Wiedermann W, Joannidis M. Hypoalbuminemia and acute kidney injury: A meta-analysis of observational clinical studies. İntensive Care Med 2010;36(10):1657-65.

9. Druml W. Nutritional management of acute renal failure. Am J Kidney Dis 2001;37(1):89-94.

10. Chertow GMAK, Lew NL, Lazarus JM, Lowrie EG. Prealbumin is as important as albümin in the nutritional assessment of hemodialysis patients. Kidney Int 2000;58(6):2512-17.

11. Perez-Valdivieso JR, Bes-Rastrollo $M$, Monedero P, de Irala J, Lavilla FJ. İmpact of prealbumin levels on mortality in patients with acute kidney injury: An observational cohort study. J Ren Nutr 2008;18(3):262-8.

12. Fraunberger $P$, Nagel $D$, Walli AK, Seidel $D$. Serum cholesterol and mortality in patients with multiple organ failure. Crit Care Med 2000;28(10):3574-5.

13. Pinilla JC, Hayes $P$, Laverty W, Arnold C, Laxdal V: The $C$-reactive protein to prealbumin ratio correlates with the severity of multiple organ dysfunction. Surgery 1998;124(4):799-805.

14. Coca SG, Yalavarthy R, Concato J, Parikh CR. Biomarkersfort he diagnosis and risk stratification of acute kidney injury: A systematic review. Kidney Int 2008;73(9):1008-16.

15. Dirkes S. Sepsis and inflammation: Impact on acute kidney injury. Nephrol Nurs J 2013;40(2):12533.

16. Assicot M, Gendrel D, Carsin H, Raymond J, Guilbaud J, Bohuon C. High serum procalcitonin concentrations in patients with sepsis and infection. Lancet 1993;341(8844):515-8.
17. Becker KL, Snider R, Nylen ES. Procalcitonin assay in systemic inflammation, infection and sepsis: Clinical utility and limitations. Crit Care Med 2008;36(3):941-52.

18. Enguix A, Rey C, Concha A, Medina A, Coto D, Dieguez MA. Comparison of procalcitonin with C-reactive protein and serum amyloid for the early diagnosis of bacterial sepsis in critically ill neonates and children. İntensive Care Med 2001;27(1):211-5.

19. Obialo $\mathrm{Cl}$, Okonofua EC, Nzerue MC, Tayade AS, Riley LJ. Role of hypoalbuminemia and hypocholesterolemia as copredictors of mortality in acute renal failure. Kidney İnt 1999;56(3):1058-63.

20. Nie $X$, Wu B, He $Y$, Huang $X$, Dai $Z$, Miao $Q$, Song $\mathrm{H}$. Serum procalcitonin predicts development of acute kidney injury in patients with suspected infection. Clin Chem Lab Med 2013;51(8):1655-61.

21. Murugan R, Kellum JA. Acute Kidney İnjury: What's the prognosis? Nat Rev Nephrol 2011;7(4):209-17.

22. Ballou SP, Kushner I. C-reactive protein andtheacutephaseresponse. AdvinternMed 1992;37(1):31336.

23. Sipe JD, Cohen AS. History of the amyloid fibril. J Struct Biol 2000;130(2-3):88-98

24. Xie Q, Zhou Y, Xu Z, Yang Y, Kuang D, You H, Ma S. The ratio of CRP to prealbumin levels predict mortality in patients with hospital-acquired acute kidney injury. BMC Nephrol 2011;12(30):1-8.

25. Bellomo R, Ronco C, Kellum JA, Mehta RL, Palevsky $P$. Acute renal failure-definition outcome measures, animal models, fluid therapy and information technology needs: The Second International Consensus Conference of the Acute Dialysis Quality Initiative (ADQI) Group. Crit Care 2004;8(4):204-12.

26. Mehta RL, Kellum JA, Shah SV, Molitoris BA, Ronco C, Warnock DG, Levin A. Acute Kidney İnjury Network: Report of an initiative to improve outcomes in acute kidney injury. Crit Care 2007;11(2):31.

27. KDIGO Clinical practice guideline for acute kidney injury. Kidney International Supplements 2012;2(1):1-36. 